\title{
Social Policy on Ageing: The Case of "Active Ageing" as a Theatrical Metaphor
}

\author{
Thibauld Moulaert ${ }^{1}$, Mario Paris ${ }^{2}$ \\ ${ }^{1}$ Institute of Analysis of Change in Contemporary and Historical Societies (IACCHOS), Université catholique de \\ Louvain, Louvain-La-Neuve, Belgium \\ ${ }^{2}$ Research Center on Aging, University of Sherbrooke, Sherbrooke, Québec, Canada \\ Correspondence: Thibauld Moulaert, Institute of Analysis of Change in Contemporary and Historical Societies \\ (IACCHOS), Université catholique de Louvain, 1348 Louvain-La-Neuve, Belgium Tel: 32-10-474-205. E-mail: \\ thibauld.moulaert@uclouvain.be
}

Received: May 15, 2013 Accepted: June 13, 2013 Available online: June 20, 2013

doi:10.11114/ijsss.v1i2.141

URL: http://dx.doi.org/10.11114/ijsss.v1i2.141

\begin{abstract}
"Active ageing" has internationally circulated as a prominent approach to meeting the challenges of an ageing population. Through the use of a theatrical metaphor as an organizing principle, this article offers a fresh look at the concept of active ageing that clarifies the origins of its definition (the "story" of active ageing and its "playwrights") and presents the scope of its action in policy through the exploration of two societal "stages" in Quebec and Belgium. By comparing these two levels ("story" "stages") and these two "stages", it helps to understand why the "comprehensive" version of active ageing developed more in Quebec while, until now, the "reduced" version to its productivist dimension is more evident in Belgium. The discussion also identifies some limits of "active ageing".
\end{abstract}

Keywords: active ageing, productive ageing, social policy, critical review

\section{Introduction}

In 2009, the United Nations claimed that the ageing of the world's population is unprecedented, pervasive, profound and enduring (UN, 2009). Population ageing leads to profound changes in society. Social policies have a significant role in shaping the ways in which changes take place. For the last 10 years, the use of "active ageing" has appeared in international social policies on ageing. It has been described as a concept (Walker, 2002), even as an aspiration (FUTURAGE, 2011), as

a comprehensive strategy to maximize participation and well-being as people age. It should operate simultaneously at the individual (lifestyle), organizational (management) and societal (policy) levels and at all stages of the life course. (Walker, 2009:86)

or as

[...] the process of optimizing opportunities for health, participation and security in order to enhance quality of life as people age" (WHO, 2002: 12).

However, other analyses claim that active ageing is remote from the real-life experience of ageing (Katz, 2000), and from significant activities identified by older adults (Clarke \& Warren, 2007). All in all, there is no consensus about what seems to be "empty rhetoric" (Boudiny, 2012).

Through the use of a theatrical metaphor as an organizing principle, the purpose of this article is to offer a fresh and critical look at active ageing. The idea of using a theatrical lexicon came from a discussion of Erwin Goffman's work on "life as a theatre" (1959). However, we do not intend to analyze active ageing from the viewpoint of everyday life, but rather in its political and narrative dimensions. As at the theatre, there are "stories" or narratives (Biggs, 2001) which are the product of a "playwright", as well as of his time. These stories have acts and an intermission, even stage directions specifying how the story should be played. Also, there are actors on a specific stage who bring what we call the "play" to life. These actors, by their individuality, adapt the story and make it their own on stage. But this theatrical metaphor is not only confined to the stage, or even to what 
goes on backstage. After all, the play is a performance in front of an audience, which includes critics who analyse and comment on the play and sometimes interact with it (Walker, 2009).

To apply these propositions, we divide our article into three distinct parts. First, we will describe the story of active ageing through its playwrights. Second, we present two plays on two "stages", one set in Quebec (Canada) and the other in Belgium. Third, we discuss the results of the comparison and present some "critics" of active ageing.

While larger international comparison should be conducted, such as Ney (2005) did for Europe, our perspective is limited to two societal stages. Behind the fact that Quebec and Belgium are the original fieldworks of the authors, these two stages have been selected to understand how the two main stories built around active ageing (comprehensive version versus productive version) take place. First, we have Quebec (Canada), where we find a play which includes many actors (e.g. researchers, governmental agencies, one Minister, non-governmental agencies, etc.). In Quebec, we observe a play in two acts. The first act concerns 7 pilot projects relating to "Age-friendly cities" and the evaluation of these projects (Garon, Beaulieu, Veil, Paris \& Bigonnesse, 2012), and the second consists of a social policy of ageing explicitly based on active ageing (Quebec Government, 2012). Second, the Belgian stage has seen a unique play with fewer actors, namely federal government and social partners such as the employers and trade unions. In 2005, Belgium centred its play on a first act that interpreted active ageing as "working longer". In 2012, the second act proposes a wider-ranging drama with more actors, including advocates of older people.

Empirically, the first section on "stories" is based on the analysis of 23 texts from international organisations about ageing policy (Moulaert \& Biggs, 2013; see also Moulaert \& Viriot Durandal, 2012 for more detailed methodological options) and 5 texts directly relating to active ageing policy (Paris, Beaulieu, Garon \& Bigonnesse, 2012a). The second section on the different stages of active ageing in Belgium and Quebec is built on previous observations in Belgium (Moulaert, 2005; 2013), Quebec (Paris, Garon \& Beaulieu, 2012b) and an empirical observation of these two cases (Moulaert, Fusulier \& Tremblay, 2011). Methodologically, we refer to the French political theory of "référentiels d'action publique" (Muller, 2006), considering "active ageing" as an idea that guides public policies. Nevertheless, this analytical framework also includes actors and institutions as it refers to the "three I" of neoinstutionalism (Palier \& Surel, 2005), i.e. the "I" for "ideas", "I" for "interests" (of actors) and "I" of "institutions" such as pension systems, job markets, etc.

\section{The "Stories" of Active Ageing}

Initially launched by major international organisations such as the OECD, WHO and European Union, active ageing is a political concept which was quickly adopted by researchers as a result of Alan Walker story's (Walker \& Naegele, 1999; Walker, 2002; 2006; 2009), although, as we shall see, a previous story existed (D’Souza, 1993).

\subsection{The International Organization's Playwrights}

Although active ageing is not explicitly used in the action plan of the first United Nations World Assembly on Ageing in 1982, its ideas were already emerging at that time. One recommendation from the action plan refers to:

Policies to meet the challenge of a growing, healthier and more active elderly population - based on the view of the ageing of society as an opportunity to be utilized - automatically benefit the individual ageing person, materially and otherwise. Similarly, any effort to ameliorate the quality of life for the elderly, and to meet their diverse social and cultural needs, enhances their capacity to continue interacting with society. (UN, 1983: 16)

As a guide for social policies on ageing, the Vienna action plan served as a basis for the development of services for older people during the 1980s and 1990s. Thus the United Nations was open to the ideas of "active life" and "social participation" for people as they grow older.

It was during the summits of the G7 in 1996 that active ageing was directly addressed for the first time. Following the ascertainment of "the crisis of ageing" (World Bank, 1994), the G7 sought a response to a "loss of human resources" that would go with population ageing. The solutions rely support for "employability" and "professional transitions". A year later, active ageing appears at the international level with "Active Aging: a shift in the paradigm" (U.S. Department of Health and Human Services, 1997), suggesting a change of story, away from the representation of old age as a period of dependency and decline.

The OECD produced a first report on active ageing in 1998 and redefined its story. At this time, active ageing was described as: 
the capacity of people, as they grow older, to lead productive lives in the society and economy. Active ageing implies a high degree of flexibility in how individuals and families choose to spend their time over life - in work, in learning, in leisure and in care-giving. (OECD, 1998: 14),

or as "the capacity of people to make flexible choices in the way they spend time over life - in learning, in work, in leisure and in care-giving" (OECD, 1998: 125). According to the OECD, the active ageing story has two features: being able to lead a productive life and being free to make personal choices. The latter means "phasing out preferential treatment for older people in disability, unemployment insurance and other social programmes, i.e., ending their role as quasi early-retirement programmes" (OECD, 1998: 20). That makes retirement more flexible and ensures "jobs for older workers". Although the OECD initially adopted a broad interpretation of active ageing, we observe that two years later it concluded that active ageing "is far too inclusive to be a manageable theme for international monitoring and sharing of experiences" (OECD, 2000: 126). A few years later, the organisation finished its international comparison with a clear title: "Ageing and employment policies. Live longer, work longer" (OECD, 2006). In other words, if we live longer, we need to work longer than before.

Since 1999, the WHO has adopted active ageing and has extended the scope of the story. To mark the UN's "International Year of Older Persons", the WHO launched a new research programme about active ageing with the slogan: "Active ageing makes the difference" (WHO, 1999). The WHO story differed greatly from the OECD story. First, the WHO studied ageing in the developing countries globally, and not exclusively employment (Kalache \& Keller, 2000). Second, it considered "older people" to be those over 60 years old, whereas the OECD had considered older people to be those over 50 years old. Third, the WHO extended the story of active ageing, based around a particular definition of health, which was regarded as a form of capital to be maintained and motivated. In addition, it should be noted that although the OECD gave its definition in 1998, the WHO did not do so until 2002:

Active ageing applies to both individuals and population groups. It allows people to realize their potential for physical, social, and mental well-being throughout the life course and to participate in society according to their needs, desires and capacities, while providing them with adequate protection, security and care when they require assistance. (WHO, 2002: 12)

According to the WHO, health is ultimately about "quality of life". Older people are not just individuals with freedom of choice, as in the OECD story: they are seen as people who are in "good health" and active (not just in employment), and as receiving social support in old age. Thus the WHO paved the way for the broadening of the active ageing story. This story was used a few years later to shift the focus to "Age-friendly cities" (WHO, 2007) and the management of human and natural disasters (WHO, 2008). Taken together, these reports (WHO, 2002; 2007; 2008) may be understood as the "trilogy" of active ageing from the WHO. However, some chapters received more attention than others from the world audience, such as the "Age-friendly cities" story. This will be illustrated further by the Quebec stage.

Finally, European Union is a third major international actor that deals with active ageing. It also inaugurates "active ageing" in late 1990's, meaning that all major international organisations deals with it around the same time. In a Communication from the Commission, EU call older people to

Preparing for longer, more active and better lives, working longer, retiring more gradually and seizing opportunities for active contributions after retirement are the best ways to secure the maximum degree of self-reliance and self-determination throughout old age. This is true even in the face of fading faculties and growing dependency. (EC, 1999: 22)

Inspired by gerontologists such as Walker (1999), the Commission proposed a comprehensive perspective at this time. However, during the 2000's, the European Employment Strategy reduced it to its productivist version (more people working longer and retiring later). In many EU countries, with different level of efficiency, national reforms followed this track (Ney, 2005). Presenting the result of EU policy in the area, Walker considers that

Despite the presence in the EU for nearly a decade of a conception of active aging based on participation and well-being across the life course, the policy instruments still focus primarily on employment (Walker, 2009: 85).

If Walker identifies several reasons to explain this observation and recalls his own 7 principles for a comprehensive approach of active ageing (see below), he finally insists onto the role of research to bring evidence-based results for policy and to focus on the well-being of the ageing population. The FUTURAGE reports he directed in 2011 is part of the answer and one may see the "EU 2012 Year of Active ageing and Solidarity between generations" as the waited answer from Europe. Interestingly, the argument for this Year (see 
EU, 2011) refers to the WHO's 2002 comprehensive framework for active ageing... and at the same time, it forgets that EC once had (EC, 1999) this perspective. While no evaluation is available at the moment for EU Year 2012, one notes the priority on employment (this being the first option next to "social participation" and "autonomy").

To sum up international organisations as playwrights, we identify two major stories that involve active ageing. First, the OECD writes about employment in later life. Second, the WHO offers a broader vision of active ageing that includes health, security and participation. Finally, EU navigates between these both approach, even if the productivist version appears dominant (Moulaert \& Biggs, 2013). Next to such organisations, gerontologists have also their own role to play.

\subsection{The Gerontologists' Playwrights}

A largely forgotten playwright may be regarded as the first author to refer explicitly to active ageing (D'Souza, 1993):

Therefore unlike the activity theory which emphasises the activity per se of the aging, the concept of Active Aging focuses on the harnessing of the potential resources of the aging for their own development and the development of society, thereby re-establishing the reciprocity between the aging and society. The recognition of the interdependence between the development of the aging and that of society would make it evident that the societal resources invested in the betterment of the aging, instead of being a drain on the economy are, on the contrary, a productive investment having both tangible and intangible benefits. (D’Souza, 1993: 342)

D'Souza promotes a positive image of ageing and recognises older people's involvement in society. However, based in India and writing his story for a local audience (the Indian journal of social work), D'Souza failed to sell his story to a larger audience. Next to the writing of a story, the promotion of it seems particularly important.

As such, sociologist and gerontologist Alan Walker can be identified as one of the most prominent playwrights on active ageing. He conceived active ageing as a means of developing a specific approach to ageing, a "European concept of active ageing" (Walker, 1999: 14-15) which would be capable of exceeding the limits of successful and productive ageing as defined by American gerontologists. Although Walker's scientific articles (2002; 2006; 2009) are often cited, the origins of active ageing should not be forgotten (Walker, 1999): it originates from a keynote paper at a conference organised by the European Commission on "the principles and potential of active ageing", co-authored with Fritz von Nordheim. Thus, from the outset, the story of active ageing lies between the story provided by international organisations and gerontologists.Although Walker has been criticised because he seemed to confine active ageing to the story of extending careers, in reality he has been aware of this limitation and the possibility that active ageing might be reduced to a mere slogan. To avoid this, Walker sets out seven principles that underlie his story of active ageing:

1. Defined in a broad sense, activity "consists of all meaningful pursuits which contribute to the well-being of the individual concerned, his or her family, local community or society at large and is not concerned only with paid employment or production. This is not to downgrade the importance of employment, it remains the leading method of inclusion, but to recognise that activity means more than work" (Walker, 1999: 15);

2. The concept should apply to all older people, "even those who are, to some extent, frail and dependent" (Walker, 1999: 16). Otherwise, there is a risk of focusing purely on the "young old";

3. Active ageing should "be primarily a preventative concept". This reflects a lifecourse perspective, in order to engage in preventive action right from an early age;

4. The concept requires a solidarity-based and inter-generational approach. This dimension means that active ageing does not only apply to older people, but is aimed at the entire population;

5. "The concept will embody both rights and obligations. Thus the rights to social protection, life-long education and training and so on may be accompanied by obligations to take advantage of education and training opportunities and to remain active in other ways" (Walker, 1999: 16);

6. The concept also involves developing empowerment strategies, i.e. supporting activity on the basis of the person him- or herself, and his or her own capabilities;

7. Finally, active ageing should respect national differences and cultural diversity.

In an article in which Walker (2009) surveys the concept, he finds that these principles suggest an obligation to develop public policies based on a partnership between older people and society. The role of the State, in such a context, would be to develop social initiatives in which older people feel informed, engaged and recognised by 
society. Here, the playwright of active ageing provides not only a story but also stage directions, or instructions about how the story should be played by the actors.

By promoting active ageing, Walker to some extent follows the story of activity theory (Havighurst \& Albrecht, 1953) and tries to exceed the limits of individualisation associated with the successful ageing story (Baltes \& Baltes, 1990) and the focus on paid work of the productive ageing story (Bass, Caro \& Chen, 1993). To give depth to Walker's story, and to fully understand the contribution of gerontology, we now situate it within other normative stories which are connected with active ageing.

Activity theory. Several critics (Bowling, 2008; Katz, 2000; Walker, 2002; Ranzjin, 2010) view active ageing as merely a successor to the "activity theory" outlined in the 1940s (Pollak, 1948), and formalised in the late 1950s (Havighurst \& Albrecht, 1953). The activity theory story states that in order to promote the well-being of the older individual, this latter must 1) engage in personal and social activities; 2) participate actively in social life; 3) seek to maintain significant roles (involvement in work or in hobbies, associations, the parish, groups of friends, etc.); and 4) find alternatives to the social roles that have been lost through retirement. Despite its various theoretical limitations, the activity theory story has managed to survive as it has passed through various gerontological approaches (Katz, 2000) - not only active ageing, but also successful and productive ageing.

Successful ageing. This story has greatly influenced gerontological practice and thinking. For the individual, "successful ageing" means adapting to the losses incurred through ageing by means of strategies of prevention (Rowe \& Kahn, 1998) and compensation (Baltes \& Baltes, 1990). This approach has been developed with a marked psychological emphasis. For Baltes \& Baltes (1990), the success of ageing is based on a threefold process of selection, optimisation and compensation in the individual, while for Rowe and Kahn (1998) it lies in the ability to maintain three individual characteristics: 1) reducing the risk of diseases and their associated disabilities; 2) maintaining maximum functioning of mental and physical capacities; 3) remaining actively engaged in life. Although Rowe \& Kahn contend that these characteristics can be arranged in a hierarchy (i.e. the absence of disease makes it easier to maintain the physical and mental functions which, in turn, make engagement in life more likely), successful ageing is more likely to be based on a combination of all characteristics that will vary for each individual.

Productive ageing. According to the productive ageing approach, activity (paid or unpaid work) is more than just a context within which individuals must adapt (successful ageing): it is of central importance. This concept emerged in the United States during the eighties. It refers to "any activity by an older individual that produces goods and services, or develops the capacity to produce them, whether they are paid for or not" (Bass et al., 1993: 6). The story emerges firstly from a refusal by a number of older U.S. workers to be limited only to family and leisure activities and, secondly, from a desire on the part of researchers to study ageing in terms of human development and life course approaches. The productive ageing story is marked by both a positive and a functionalist approach to ageing, which asserts the value of the role given to older people. The problem with this concept is essentially the limits of its definition of productive activity. Should we recognise undeclared work? How can we attribute financial value to caregiving and housekeeping so that they are considered productive? Walker and Taylor (1993) note that public interventions that draw on productive ageing are likely to overlook some forms of work that are arduous for workers and to include only paid work, although it theoretically also refers to voluntary work.

To summarise the functioning of researchers in ageing as playwrights, this extends the scope of active ageing stories, with the result that "contemporary policy on ageing evidences a change of emphasis, from responses to isolated problems [...] to attempts to proscribe what it is to age well and responsibly". Estes and her colleagues consider that "these solutions to the 'problem of ageing' are seductive to gerontology, because they seem to promise answers to age prejudice and marginalization" (Estes, Biggs \& Phillipson, 2003: 4).However, the enunciation of a "playwright" is not enough as actors may use and adapt it under certain circumstances. For such a reason, we will now compare Quebec and Belgium in order to understand how actors prefer to follow one interpretation or another.

\section{Playing the Story of Active Ageing}

Quebec (Canada) and Belgium constitute the stages for our discussion of active ageing. Here, the metaphorical idea of the play illustrates the particularity of each case and explains why the Belgian has mainly be conducted by the productivist approach of active ageing, while Quebec mainly observe its comprehensive approach.

\subsection{The Belgian Stage}

Clearly, in Europe, the story of active ageing has frequently been played within the broader theme of reforming 
pension systems or the labour market (Guillemard, 2010) so as to prevent any discrimination on the basis of age (Walker \& Taylor, 1998). Like other Member States, Belgium has been described (Moulaert, 2013) as a good example of a country that has had great difficulty in implementing such reforms because of a strong "culture of early retirement" (Guillemard, 2010). Therefore active ageing has most commonly been enacted in various employment and pension reforms at national level (Ney, 2005). In 2005, the "Conference on the end of career" (Moulaert, 2005) illustrates the first "act" of the Belgian active ageing play. The second "act" emerged at the end of 2011, at the instigation of the European Commission.

Act 1. In Belgium, active ageing represents a response to the end-of-career debate about the underemployment of "older workers", that is, those aged between 55 and 64 years in EU's perspective. However, the active ageing play included not only the transformation of institutional measures (reforms of the early retirement system, new incentives for outplacement, financial incentives for employers to hire older workers, etc.), but also changes in the socio-political discourse. That discourse became centred on the active welfare state (Vandenbroucke, 1999) with the participation of older workers. One can perceive the symbolic shift from an "unemployment reduction policy towards a policy of active ageing" (Burnay, 2005). The Belgian State became involved in the participation not only of individuals facing retirement and end-of-career issues but also in the mechanisms to manage them. The process involved encouraging people to extend their career either with incentives (including financial ones) or through coercion (requiring workers aged $45+$ to submit to an outplacement procedure under threat of unemployment allowance suspension), or both, while hoping that they will reduce their working hours without severing their employment ties (Moulaert, 2013).

In the run-up to the 2005 Solidarity Pact, different reports had been produced by economists, especially that of the High Council for Employment (CSE, 2004) that "inspired" the Prime Minister. Interestingly, this report made use of the ideas on active ageing put forth by European Commission and OECD at this time; what was new was the shift of emphasis away from the unemployment rate onto the employment rate. In short, the first "act" was played by the federal government and, in particular, the Prime Minister, with the support of economists. The role of employers was also very important as they push the government to follow the productivist version of active ageing; on the contrary, trade unions have been unable to take the advantage of such conception, one of the reasons being their internal divisions, another being the low audience of the argument concerning "workplace adaptation" for older workers, at least at this time and in this context. At the time, older people's representatives and associations were not an actor, because they were not consulted by the government. Things happened differently in the second act.

Act 2. The second "act" started at the end of 2011 and will be played until the end of 2012, as Europe calls on its Member States to organise their own activities to celebrate the "2012 European Year for Active Ageing and Solidarity between Generations" (EU, 2011). Here again, we observe the impetus originating from the European level. However, this is the only parallel with Act 1, and two important differences emerge. Firstly, the initial interpretation of active ageing is no longer centred solely on "working longer". The European institutions have identified three main areas (employment; social participation; independent living), but the Belgian perspective has added another area, that of health and well-being, and the potential for a transversal policy on active ageing has also been stressed (Burnay, Moulaert, Declercq \& Lurkin, 2012). Secondly, because the discussions on the meaning of active ageing, i.e. the Belgian stage directions, no longer focus exclusively on "working longer" (although this is still very important), the actors are not only the traditional social partners and the State. Now, they are included within the generic term of "stakeholders", which also refers to civil society, non-governmental organisations and the official representatives of Regional (Flemish and Walloon) councils of older people. The latter can even be regarded as the "leading actor" if it illustrates the rise of a grey power: Viriot Durandal, 2003) in Belgium. This increasingly important political voice of older people has ascended from its original position within older people's associations at local level (senior citizen advisory councils are found in $90 \%$ of Flemish cities and in 50\% of Walloon cities), reaching Regional level and, by the end of 2012, it leads to the creation of a Federal Consultative Council of Older People. While this actor has had a virtual existence in legal texts since 2007, the European Year has been a clear driver for its recognition.

\subsection{The Quebec Stage}

In Quebec, the active ageing play is also marked by an extension of careers and the modification of retirement arrangements (Lesemann \& D'Amours, 2006). Here, it is also possible to identify "actors" that support the extension of paid activity ${ }^{2}$. However, such interpretation of active ageing did not receive much attention. A reason is that Quebec may be associated with a more liberal market (in comparison with Belgium) where the position of older workers in job market is less regulated according to Guillemard perspective (2010). 
What is much clearer, is the contribution of Canada to the WHO's transcription of active ageing into the "Age-friendly cities" (AFC) program, i.e. "An age-friendly city encourages active ageing by optimizing opportunities for health, participation and security in order to enhance quality of life as people age" (WHO, 2007: 1). This is illustrated by the conception the "Vancouver's Protocol", a qualitative methodology to assist cities to assess the needs and perceptions of older people concerning their life in the city. While many Canadian provinces built their own plans of actions and Anglo-Canadian researchers took an active part in AFC like in Manitoba (Menec, Means, Keating, Parkhurst \& Eales, 2011), the study of Quebec province is of particular interest as it has been cited in example by WHO at different occasions (Plouffe, 2011). As is the case in Belgium, we isolate two "acts" from the Quebec play.

Act 1. AFC projects in Quebec have explicitly taken Walker's story as the basis for their concept of active ageing (Paris et al., 2012b) in order to develop a play in which older people feel informed, engaged and recognised by society. Also, the play of active ageing in Quebec has sought to provide a response to one of the recommendations of the Madrid International Plan of Action on Ageing, that older people should be given wider participation in public policy decision-making processes (Garon, Beaulieu \& Veil, 2008). In other words, rather than addressing the needs of the population, including older people, from a traditional top-down model, AFC projects seek to involve everyone in the development and implementation of new social policies and programmes (UN, 2006). In all, more than 579 communities and cities (covering over 55\% of Quebec's population) have started to implement AFC projects. This participatory approach is designed to minimise the input of the top-down model, in which people are the object of interventions, and instead foster a bottom-up model promoting collaboration between the State and the community. Despite the pitfalls associated with a participatory approach (Pretty, 1995), the point remains that the primary purpose of AFC in Quebec is to engage the different stakeholders in the general welfare of older people. Thus, it is not only older people themselves that are affected by AFC projects in Quebec, but also community leaders and local stakeholders who are concerned about population ageing and older people's well-being (Garon et al., 2008). Quebec has a long tradition of community building (Bourque, 2008), and the play of active ageing has therefore been enacted by several social actors, including members of civil society, older people's associations, municipal government and policy-makers. In such a deployment of active ageing, the challenge is to understand how various actors have interpreted their roles and the story developed by Walker.

Act 2. The second "act" of the active ageing play in Quebec takes place with the announcement of the first policy on ageing: "Ageing and living together" (Quebec Government, 2012). This policy relies explicitly on the WHO story of active ageing and identifies three main directions: 1) participation by older people in their communities; 2) healthy living in their communities for older people; and 3) creating healthy, safe and welcoming environments in older people's communities (Quebec Government, 2012). The policy is accompanied by a governmental action plan that aims to integrate older people in the realisation of actions, mobilise national, regional and local stakeholders, and take into account the specific characteristics of each community. To do this, the policy has developed its own stage directions, in the form of two approaches. First, because there are so many issues associated with population ageing, the policy promotes intersectoral participation and collaboration between all actors. Second, community building is a cornerstone of the policy, because actions should be for and by communities. Although the policy does not refer to the work of Walker, we observe some elements of his story: collaboration, community building, empowerment, diversity, etc.

\section{Discussion}

What are the results of theatrical lexicon as an organizing principle to analyse active ageing discourse and policy? How are the "ideas", "interests" of actors and "institutions" linked together? How to understand that Quebec developed a comprehensive approach of active ageing while Belgium stayed concerned by its productivist approach?

First, it helps to describe the two different stories of "active ageing" (comprehensive versus productivist); local stages also express different "play" of such stories. The Belgian stage presents the predominance of a productivist discourse because dominant actors are those concerned with work and employment discussion, employers or government being able to mobilise EU idea of active ageing in employment in the first act, a bit less in the second. If dominant, this story may be challenged by the comprehensive approach that gives voice to older people representatives, as it slightly emerged in the second act. Nevertheless, it is unclear if they will obtain a real power in policy. Here, the "comprehensive" idea of active ageing leaves them alone. In Quebec, the situation is upside-down. Active ageing has never been strongly used by employment actors. They leave the situation of older workers to the relative free market institution (freer than in Belgium). On the opposition, the WHO definition quickly concerns a practical case, i.e. the "Age Friendly Cities" one (AFC). Originally part of 
the WHO's program (WHO, 2007), it emancipates from it through the connexion of researchers and policy at the occasion of the large consultation by Minister of Older people and Family. The progressive enlargement of AFC to 579 municipalities in Quebec in act one and the production of an extensive public policy in act two are both linked to a longstanding use of active ageing by researchers and policy makers. Together, they start building a form of "epistemic community" (Bossy \& Evrard, 2010). Such community never happens in Belgium around the comprehensive approach of active ageing. At least until now.

A second point we learn from this comparison is an ambivalence of "active ageing". The story of active ageing, due to its link with "active theory", is unable to integrate the notion of decline into its play. As mentioned by Biggs Phillipson, Money and Leach (2006), in the past few years several authors have welcomed the transformation of public policy discourses because old age has never been so presented in such a positive light. However, this emphasis on active, successful or productive ageing can paradoxically undermine the value of or reject certain individual experiences associated with old age, such as disease, infirmity, impotence, frailty or vulnerability (Cardona, 2008). None of these can easily be integrated into the analysis of ageing by mainstream gerontology, because they tend to be seen as a sign of the "decline model" or "deficit model" (Phillipson, 1998).

By promoting productivity and employability in its productivist version or by insisting (too) much on social participation in its comprehensive version, active ageing stories reproduce a normative ageing between a normal and a pathological lifecourse. According to Holstein and Minkler, this concept of normative ageing is important because "[...] we are situated selves, embedded in society and culture and resonating with what is valued in the environment" (Holstein \& Minkler, 2003: 791). For a number of researchers (Biggs et al., 2006 ; Featherstone \& Hepworth, 1990), old age has lost its symbolic and cultural references, whereas youth has made corresponding gains: "Older citizens are encouraged not just to dress 'young' and look youthful, but to exercise, have sex, take holidays, socialise in ways indistinguishable from those of their children's generation" (Blaikie, 1999: 104). Biggs et al. (2006: 242) ironically commented: "Nobody, it seems - in the sense of dependency, withdrawal from society, plus a limited ability to both produce and consume - is old anymore". Here, our analysis comes to complete such existing literature.

Finally, our theatrical metaphor as an organizing principle contains two limits. First, it may exaggerate the importance on some actors, this being illustrated by our focus on Alan Walker. Clearly, this calls for more research on networking between researchers, policy officers at international and national levels, members of international organisations. For example, if we briefly mentioned the role played by Canada to support WHO's work on AFC, this would be useful to describe the whole networks of people working for that, their educational background and their affiliation. This would probably differ from the networks behind the OECD's or EU's conception of active ageing. Again here, this may drive us to insist on the importance of an "epistemic community" (Bossy \& Evrard, 2010). Furthermore, such networks may transform in the long run. This is a second limit of our work. While we isolated distinctive positions facing active ageing between international organisations and local applications, this is only a relatively stable picture. If we explore the continuities/discontinuities of the international organisations' positions elsewhere (Moulaert \& Viriot Durandal, 2013), one must be conscious that discourses (and practices) are rarely fixed once for all.

\section{Acknowledgements}

The authors would like to thank Prof. Alan Walker for his comments on a previous version of this article, Prof. Suzanne Garon and Prof. Marie Beaulieu for their exchanges of ideas with us and Prof. Simon Biggs for his encouragements.

This work was financially supported by the Fund for Scientific Research - Belgium (FRS-FNRS) through a postdoctoral fellowship to first author.

\section{References}

Baltes, P. B., \& Baltes, M. M. (1990). Successful Aging: Perspectives From the Behavioral Sciences. Cambridge, NY: Cambridge University Press.

Bass, S. A., Caro, F. G. \& Chen, Y.-P. (1993). Achieving a Productive Aging Society. Westport, Conn.: Auburn House.

Biggs, S. (2001). Toward critical narrativity: Stories of aging in contemporary social policy. Journal of Aging Studies, 15(4), 303-316. http://dx.doi.org/10.1016/S0890-4065(01)00025-1

Biggs, S., Phillipson, C., Money, A., \& Leach, R. (2006). The age-shift: Observations on social policy, ageism and the dynamics of the adult lifecourse. Journal of Social Work Practice, 20(3), 239-250. http://dx.doi.org/10.1080/02650530600931708 
Blaikie, A. (1999). Ageing and Popular Culture. Cambridge: Cambridge University Press.

Boudiny, K. (2012). 'Active ageing': From empty rhetoric to effective policy tool. Ageing \& Society. August, 1-22. Retrieved from http://dx.doi.org/10.1017/S0144686X1200030X.

Bourque, D. (2008). Concertation et partenariat, Entre levier et piège du développement des communautés [Dialogue and partnership. Between lever and trap for the development of communities]. Quebec: Presses de l'Université du Québec.

Bossy, T., \& Evrard, A. (2010). Communauté épistémique [Epistemic community]. In L. Boussaguet, S. Jacquot \& P. Ravinet (Eds.), Dictionnaire des politiques publiques (pp. 140-147). Paris: Presses de Sciences Po.

Bowling, A. (2008). Enhancing later life: How older people perceive active ageing. Aging and Mental Health, 12(3), 293-301. http://dx.doi.org/10.1080/13607860802120979

Burnay, N. (2005). Travailleurs âgés. D'une politique de réduction du chômage à une politique du vieillissement actif [Older workers. From a policy of reducing unemployment towards a policy of active ageing]. In P. Vielle, P. Pochet \& I. Cassiers (eds.), L'État social actif. Vers un nouveau paradigme? (pp. 209-232). Brussels: Peter Lang.

Burnay, N., Moulaert, T., Declercq, A., \& Lurkin, F. (2012). Belgian Active Ageing 2012: Le vieillissement actif au pluriel. Final Report for EY 2012. Brussels: Service public Sécurité sociale, DG Appui stratégique.

Cardona, B. (2008). "Healthy ageing" policies and anti-ageing ideologies and practices: on the exercise of responsibility. Medicine, Health Care, and Philosophy, 11(4), 475-483. http://dx.doi.org/10.1007/s11019-008-9129-z

Clarke, A., \& Warren, L. (2007). Hopes, fears and expectations about the future: What do older people's stories tell us about active ageing? Ageing \& Society, 27(4), 465-488. http://dx.doi.org/10.1017/S0144686X06005824

Conseil supérieur de l'emploi [CSE]. (2004). Rapport annuel [Annual report]. Brussels: SPF Emploi Travail et Concertation sociale.

D'Souza, V. (1993). The concept of active aging. Indian Journal of Social Work, 54(3), 333-344.

European Commission [EC]. (1999). Communication From the Commission, Towards a Europe for All Ages Promoting Prosperity and Intergenerational Solidarity, COM(1999) 221 final. Retrieved from http://ec.europa.eu/employment_social/social_situation/docs/com221_en.pdf

Estes, C., Biggs, S., \& Phillipson, C. (2003). Social Theory, Social Policy and Ageing: A Critical Introduction. London: Open University Press.

European Union [EU]. (2011). Decision No 940/2011/EU of the European Parliament and of the Council of 14 September 2011 on the European Year for Active Ageing and Solidarity between Generations (2012). Retrieved from http://eur-lex.europa.eu/LexUriServ/LexUriServ.do?uri=OJ:L:2011:246:0005:0010:EN:PDF

Featherstone, M., \& Hepworth, M. (1990). Images of ageing. In M. Featherstone \& A. Wernick (eds.), Images of Ageing (pp. 29-48). London: Routledge.

FUTURAGE. (2011). The Future of Ageing Research in Europe: A Road Map. Sheffield University.

Garon, S., Beaulieu, M., \& Veil, A. (2008). Le programme Villes amies des aînés de l'Organisation mondiale de la santé: une occasion de reconnaissance pour les aînés [The WHO's Age-friendly cities programme: an opportunity to recognise older people]. Éthique publique, 10(2), 117-125.

Garon, S. Beaulieu, M., Veil, A., Paris, M., \& Bigonnesse, C. (2012). L’expérience québécoise du programme «Villes-amies des aînés » de l'OMS : l'implantation dans sept projets-pilotes [Quebec's experience of the WHO "Age-friendly cities" programme: implementing seven pilot projects]. In J.-P. Viriot-Durandal, C. Pihet \& P.-M. Chapon (eds.), Les défis territoriaux face au vieillissement (pp. 69-88). Paris: Documentation française.

Goffman, E. (1959). The Presentation of Self in Everyday Life. Anchor Books.

Quebec Government. (2012). Vivre et vieillir ensemble. Chez soi, dans sa communauté, au Québec [Aging and Living Together. At Home, in the Community, in Quebec]. Quebec: Gouvernement du Québec. Retrieved from http://www.mfa.gouv.qc.ca/fr/publication/Documents/politique-vieillir-et-vivre-ensemble.pdf

Guillemard, A.-M. (2010). Les défis du vieillissement. Age, emploi, retraite. Perspectives internationales [Ageing challenges. Age, employment, retirement. International perspectives]. Paris: Armand Colin. 
Havighurst, R., \& Albrecht, R. (1953). Older People. New York: Longmans, Green and Co.

Holstein, M., \& Minkler, M. (2003). Self, society, and the 'new gerontology'. Gerontologist, 43, 787-796. http://dx.doi.org/10.1093/geront/43.6.787

Kalache, A., \& Keller, I. (2000). The greying world: a challenge for the $21^{\text {st }}$ century. Science progress, $83(1)$, 33-54.

Katz, S. (2000). Busy Bodies: Activity, aging, and the management of everyday life. Journal of Aging Studies, 14(2), 135-152. http://dx.doi.org/10.1016/S0890-4065(00)80008-0

Lesemann, F. \& D'Amours, M. (2006). Vieillissement au travail, emplois et retraites [Ageing at work, employment and retirement]. Montreal: Éditions Saint-Martin.

Menec, V. H., Means, R., Keating, N., Parkhurst, G., \& Eales, J. (2011). Conceptualizing Age-Friendly Communities. Canadian Journal on Aging / La Revue canadienne du vieillissement, 30(3), 479-493. http://dx.doi.org/10.1017/S0714980811000237

Moulaert, T. (2005). La fin de carrière. Des politiques en débat [The end of career. Politics debate]. Courrier hebdomadaire du CRISP, 1882.

Moulaert, T. (2013). L'outplacement des 45 ans et plus en Belgique, tentative avortée de "gouvernement à distance" des fins de carrière ? [Outplacement for those aged 45+ in Belgium: a failed attempt at "government at a distance" for the end of career?]. Retraite et société, 64, 107-131. www.cairn.info/revue-retraite-et-societe-2013-1-page-107.htm

Moulaert, T., \& Biggs, S. (2013). International and European policy on work and retirement: Reinventing critical perspectives on active ageing and mature subjectivity, 66(1), 23-43. http://dx.doi.org/10.1177/0018726711435180

Moulaert, T., Fusulier, B., \& Tremblay, D.-G. (2011). Management of working time for career extension in Belgium and Quebec. Population Review, 50(1), 138-155.

Moulaert, T., \& Viriot Durandal, J.-P. (2012). Le "vieillissement actif" sur la scène internationale : perspectives méthodologiques pour l'étude d'un référentiel polymorphe [Active ageing on the international scene: Methodological perspectives on the study of a polymorphic notion]. Les politiques sociales, 72(1-2), 10-21.

Moulaert, T., \& Viriot Durandal, J.-P. (2013). De la notion au référentiel international de politique publique : Le savant, l'expert et le politique dans la construction du vieillissement actif [From notion to public policy referential : The scholar, the expert and the policy officer in the construction of active ageing]. Recherches sociologiques et anthropologiques, 44(1).

Muller, P. (2006). Les politiques publiques [Public policies]. Paris: Presses Universitaires de France, Que sais-je ?

Ney, S. (2005). Active aging policy in Europe: Between path dependency and path departure. Ageing International, 30(4), 325-342. http://dx.doi.org/10.1007/s12126-005-1019-6

Organisation for Economic Cooperation and Development [OECD]. (1998). Maintaining Prosperity in an Ageing Society. Paris: OECD editions.

OECD. (2000). Reforms for an Ageing Society. Paris: OECD editions.

OECD. (2006). Ageing and Employment Policies. Live Longer, Work Longer. Paris: OECD editions.

Palier, B., \& Surel, Y. (2005). Les "trois I" et l'analyse de l'État en action [The "three I" and the analysis of State in action]. Revue française de science politique, 55(1), 7-32. http://dx.doi.org/10.3917/rfsp.551.0007

Paris, M., Beaulieu, M., Garon, S., \& Bigonnesse, C. (2012a). "Selon le temps, la manière", ou comment situer "Villes-amies des ainés" dans l'évolution des cadres internationaux d'orientation sur le vieillissement? ["Finding a way to suit the time", or how should "Age-friendly cities" be situated in the evolution of international policies on aging?]. Canadian Review on Social Policy, 68-69, 10-23.

Paris, M., Garon, S., \& Beaulieu, M. (2012b). Le projet "Villes-amies des aînés au Québec" [The project "Age-friendly cities in Quebec"]. Les politiques sociales, 72(1-2), 91-100.

Phillipson, C. (1998). Reconstructing Old Age: New Agendas in Social Theory and Practice. London: Sage Publications.

Plouffe, L. (2011). Villes amies des aînés : de ses origines à son déploiement international [Age-friendly cities: from its origins to its international expansion]. Vie et Vieillissement, 9(1), 14-18. 
Pollak, O. (1948). Social Adjustment in Old Age: A Research Planning Report. New York: Social Science Research Council. Bulletin 59.

Pretty, J. N. (1995). Participatory learning for sustainable agriculture. World Development, 23(8), 1247-1263. http://dx.doi.org/10.1016/0305-750X(95)00046-F

Ranzijn, R. (2010). Active ageing: Another way to oppress marginalized and disadvantaged elders? Aboriginal elders as a case study. Journal of Health Psychology, 15(5), 716-723. http://dx.doi.org/10.1177/1359105310368181

Rowe, J. W., \& Kahn, R. L. (1998). Successful Aging. New York: Pantheon Books.

United Nations [UN]. (1983). Vienna International Plan of Action on Aging. New York: United Nations.

UN. (2006). Guidelines for Review and Appraisal of the Madrid International Plan of Action on Ageing. New York: United Nations.

UN. (2009). World Population Ageing. New York: United Nations.

U.S. Department of Health and Human Services. (1997). Active Aging: A Shift in the Paradigm. Washington. Retrieved from http://aspe.hhs.gov/daltcp/reports/actaging.pdf

Vandenbroucke, F. (1999). L'État social actif : une ambition européenne [The active welfare state: a European ambition]. Paper presented at the Exposé Den Uyl, Amsterdam.

Viriot Durandal, J.-P. (2003). Le pouvoir gris : sociologie des groupes de pression de retraités [Grey power: sociology of retired pressure groups]. Paris: Presses Universitaires de France.

Walker, A. (1999). The Principles and Potential of Active Ageing, Keynote Introductory Report. Paper presented at the European Commission conference on Active ageing, Brussels.

Walker, A. (2002). A strategy for active ageing. International Social Security Review, 55(1), 121-139. http://dx.doi.org/10.1111/1468-246X.00118

Walker, A. (2006). Active ageing in employment: It's meaning and potential. Asia-Pacific Review, 13(1), 78-93. http://dx.doi.org/10.1080/13439000600697621

Walker, A. (2009). Commentary: The Emergence and Application of Active Aging in Europe. Journal of Aging \& Social Policy, 2l(1), 75-93. http://dx.doi.org/10.1080/08959420802529986

Walker, A., \& Naegele, G. (1999). The Politics of Old Age in Europe. Buckingham, England: Open University Press.

Walker, A., \& Taylor, P. (1993). Ageism versus productive aging: The challenge of age discrimination in the labor market. In S. A. Bass, F. G. Caro \& Y.-P. Chen (eds.), Achieving a Productive Aging Society (pp. 61-79). Westport, Conn.: Auburn House.

Walker, A., \& Taylor, P. (1998). Combating Age Barriers in Employment: a European Portofolio of Good Practice. Dublin: Fondation européenne pour l'amélioration des conditions de vie et de travail.

World Health Organisation [WHO]. (1999). WHO Launches Project to Support 'Active Ageing'. Retrieved from http://www.who.int/inf-pr-1999/en/pr99-wha16.html

WHO. (2002). Active Ageing. A Policy Framework World Health Organization to the Second United Nations World Assembly on Ageing. Madrid: WHO.

WHO. (2007). Global Age-friendly Cities: A Guide. Geneva: WHO.

WHO. (2008). Older Persons in Emergencies: An Active Ageing Perspective. Geneva: WHO.

World Bank. (1994). Averting the Old Age Crisis. New York: Oxford University Press.

\section{Notes}

Note 1: G8 information centre, Conclusions of the Chair. Retrieved from http://www.g8.utoronto.ca/employment/labour1996.htm

Note 2: See for example the actors of Innov-Âge, www.innov-age.com [accessed August 30, 2011].

\section{$(\mathrm{cc}) \mathrm{Br}$}

This work is licensed under a Creative Commons Attribution 3.0 License. 